\title{
Fighting the War at Home: Strategic Narratives, Elite Responsiveness, and the Dutch Mission in Afghanistan, 2006-2010 ${ }^{1}$
}

\author{
George Dimitriu \\ Netherlands Defence Academy \\ AND \\ Beatrice de GraAf \\ Utrecht University
}

\begin{abstract}
This paper analyzes the Dutch deployment in Uruzgan between 2006 and 2010 with an eye to the challenge of garnering public support for protracted military missions abroad. The hypothesis is that public support can be shaped and sustained by strategic narratives regarding the use of force. Ringsmose and Børgesen's model on strategic narratives is discussed and tested, and expanded in two ways. First, by including the role of "counternarratives," that is, of narratives presented by factions that oppose deployment decisions. Our data suggest that narrative dominance (the combination of narratives and counternarratives) accounts for the waxing and waning of public support for a given mission. Second, the nexus between negative narrative dominance and the ensuing drop of public consent will be teased out. Using the notion of "elite responsiveness," we demonstrate when and how weak strategic narratives trigger a political fallout.
\end{abstract}

From 2006 to 2010, the Netherlands was the lead nation of the International Security Assistance Force (ISAF) in the Afghan province of Uruzgan. During that period, the Netherlands made a significant contribution to the NATO mission with 2,000 military and scores of civilian personnel per rotation, the largest Dutch deployment since the Korean War. Over the course of the mission, the Dutch forces suffered 25 fatalities (Official Parliamentary Reports, no. 330). During the Dutch deployment, opposition to the mission steadily increased. On February 20, 2010, the Dutch coalition government headed by Prime Minister Jan Peter Balkenende collapsed after a conflict over a second extension of the Dutch mission in Afghanistan. Balkenende's center-right Christian Democrats (CDA) wanted to discuss a NATO request to extend the Dutch presence in Afghanistan, whereas the Labor Party (PvdA) bitterly opposed an extension. Labor Party leader

\footnotetext{
${ }^{1}$ The authors express their thanks to the FPA editors and reviewers for their assistance and advice. The article also profited from the comments provided by Jaap de Hoop Scheffer, Jens Ringsmose, and John Kok. A shorter introduction to the political decision-making process regarding the TFU in the Netherlands will be printed as chapter in the volume edited by George Dimitriu, Beatrice de Graaf, and Jens Ringsmose, Strategic Narratives, Public Opinion and War: Winning Support for Foreign Military Missions, forthcoming 2014/2015.
} 
Wouter Bos resigned from the government, thereby effectively bringing an end to the coalition and to the mission in Uruzgan.

This downfall of the government in 2010 marked the end of a long, winding, political, and public debate on the purpose and utility of the mission in Uruzgan. From the onset in 2005, when the ruling government at that time decided to deploy forces to the Southern Afghan province, the debate had been hijacked by the dichotomy of the "combat mission" and the "reconstruction mission" (Dimitriu and de Graaf 2010). Similar discussions in other countries where participation in the ISAF was at stake were also stalemated (Suhrke 2008). However, while some governments struggled with dwindling popular support and sharply dismissive criticism of the mission, other administrations were able to garner and sustain steady and sufficiently strong public support-even though troops were deployed to the same war-torn regions and provinces (Ringsmose and Børgesen 2011).

This paper addresses the fundamental question of mobilizing and sustaining public support for the use of force abroad in protracted military missions. Can waning public support in the Netherlands for the deployment of military troops to Afghanistan be explained? Could this lack of sustainable support be related to the strategic narratives of national policymakers on the use of force? It has been argued extensively that public support is shaped by the cohesion and content of the strategic narratives employed by national policymakers. Building on the work of, among others, Lawrence Freedman, we understand strategic narratives to be "compelling story lines which can explain events convincingly and from which inferences can be drawn" (Freedman 2006:22).

The question here is how the Dutch government crafted a strategic narrative to explain its decision to participate in ISAF, how this narrative was perceived in the public square, and subsequently, how successful it was politically, that is, to what extent were the government's goals, interests, and actions understood and accepted by the political parties represented in the Dutch parliament. In answering this question, we will consider how the Dutch government employed its narrative with an eye to mobilizing political and public support for the deployment of forces to Uruzgan in 2006 and how it ultimately lost its political mandate in 2010. We do so by presenting a quantitative analysis of these narratives and the response they solicited. While it has been argued before that strategic narratives may mobilize and influence public support of military missions (Freedman 2006; Ringsmose and Børgesen 2011), there is still not much empirical evidence to tease out this relation. We attempt to address and bridge this gap with a quantitative analysis of the strategic narratives presented in Dutch national newspapers, paying special attention to fluctuations in public support. Based on a large data set, we identified a correlation between the dominant narrative and the level of public support.

We make use of Ringsmose and Børgesen's model of measuring the effect of strategic narratives regarding the use of force in military missions abroad (2011). We start with a theoretical debate regarding the relation between public opinion and the use of force and then turn to the role of strategic narratives in explaining how government policy is translated into public and political support (or not). Based on an empirical analysis of the public and political debate in the Netherlands on the military mission to Uruzgan (2006-2010), we conclude that strategic narratives and counternarratives do influence the public's opinion about a given mission. To be more precise, we introduce two new elements into the theory on strategic narratives and the use of force. First of all, the relative weight of strategic narratives as measured against the counternarratives presented by the opposition and in the media-which we indicate as "narrative dominance"-constitutes the independent variable that shaped Dutch public opinion. Second, whereas narrative dominance does condition public support 
for a given mission, it does not automatically translate into a congruent political decision in this respect. The specific elite response to public opinion and narrative dominance is, of course, conditioned by a number of elements, including the political system's infrastructure, the media landscape, and the domestic military culture.

\section{Public Opinion and the Use of Force}

Since the rise of public opinion research, the relation between public opinion and foreign policy has been studied extensively. The first generation of public opinion scholars held the realist view that public attitudes to foreign policy were highly volatile, irrational, lacking coherence, and structure, that "the public" was not capable of making informed decisions on the use of force anyway and would reflexively "rally" round the flag as soon as war was declared (Almond 1950; Verba et al. 1967; Holsti 1992, 2004; Foyle 1999). This viewpoint changed drastically during the Vietnam War, after which scholars embraced the existence of a more direct exchange between foreign policy and public opinion (Holsti 1992; Gelpi, Feaver, and Reifler 2009). The relationship between public opinion and the use of armed force has been identified as "the essential domino" (Klarevas 2002:417). Obviously, the post-Vietnam consensus about the primacy of public opinion created a strong impetus for studying the formation of public preferences.

A popular view that emerged during the Vietnam War and increasingly gained currency was that public support for military operations decreases when the number of casualties increases-also known as the "body bag syndrome." As summarized by Edward Luttwak (1996): "The prospect of high casualties, which can rapidly undermine domestic support for any military operation, is the key political constraint when decisions must be made on which forces to deploy in a crisis, and at what levels." John Mueller asserts that public support for military operations can be explained with a "simple association: as casualties mount, support decreases" (Mueller 1973, 2005:44).

Numerous scholars have built on Mueller's work, adding more contextual factors to his rather monocausal explanation. Luttwak (1996) argues, for example, that the public is less casualty-tolerant nowadays due to lower birth rates. Sapolsky and Shapiro (1996) hold that technological developments reinforced casualty phobia by nurturing unrealistic expectations regarding our ability to prevent casualties. As a consequence of the "televised war," near-real-time images of the shocking events of war cause a vividness and immediacy that easily sways public opinion (Neuman 1996; Gelpi et al. 2009). Notwithstanding these findings, an increase in casualties does not always lead to a decrease of popular support for the deployment of forces (Larson and Savych 2007; Howell and Kriner 2008, unpub. data). An analysis of Dutch public opinion polls and Dutch casualties underscores that point: Although support for military missions did indeed dwindle gradually, the decreases did not correlate with lethal incidents (Everts 2008; Van der Meulen and Vos 2008).

The question remains, if casualties do not seem to change public opinion on war unequivocally, what does? While most scholars acknowledge that public support is vital to successful military operations (Klarevas 2002:417), they do think differently about what ultimately determines this public support. What moves people to support the deployment of troops and how can this acquired support be sustained? In his useful overview, Louis Klarevas (2002), while synthesizing existing work on this issue, concludes that one important factor can be described as the perceived "relative value" of a military mission-a sort of cost-benefit calculation, with fatalities as the key cost. A second factor has to do with the level of elite consensus on a given mission (2002:424-26; see also Gelpi et al. 2009; 
Baum and Groeling 2010). Other factors relate to the perceived vitality of the interests at stake (Ladd 1980), the level of multilateral support for the mission (Kull and Destler 1999), the attributed legitimacy of a given mission (Wecke 2008:162), or the policy objectives as formulated (Jentleson 1992). Finally, many scholars point to the importance of the information revolution and the mediatization of war, which makes it impossible to leave public opinion unaware of and unaffected by military operations anymore (Molander 1996; Arquilla 2001).

However, despite these valuable insights, public opinion is not a static entity for politicians to empirically measure and assess and calibrate their decisions to. On the contrary, several scholars examining the relationship between foreign policy and public opinion have claimed that public opinion is a highly volatile entity and very responsive to elite rhetoric. As Baum and Groeling point out, if a public observes consistent elite rhetoric with respect to a given foreign policy issue, they tend to respond favorably to the elite's decision making. And the opposite holds true as well. In the face of persistent elite bickering, public opinion displays a tendency to fragmentize as well, falling apart along partisan lines (Zaller 1994; Holsti 2004; Berinsky 2009; Baum and Groeling 2010). Thus, political elites are themselves responsible for and capable of mobilizing and preserving the unity of public support for troop contributions to war. Hans Morgenthau (1948), already decades ago, stated that it would be a mistake to consider "public opinion" as an absolute entity that can be calculated and gauged without taking into account that it is constantly in flux. Public opinion changes, evolves, and is being constructed and deconstructed through political rhetoric or new revelations (Brody 1991).

In line with these insights, we argue that the ability of the political elite to shape, mold, and mobilize support for military deployment deserves a much more thorough analysis. The concept of "strategic narrative" offers a highly useful and fruitful tool to do so. Recent research indicates that the public's perception of a war is shaped by explicitly crafted strategic narratives that governments construct and communicate in order to convey a sense of cause, purpose, and mission (Freedman 2006; Roselle 2010; Ringsmose and Børgesen 2011). In this paper, we build on the growing literature on strategic narratives, partly by testing existing theories of strategic narratives and partly by developing new theoretical insights regarding the role of strategic narratives in the nexus between government policy and public support for the use of force. These insights primarily regard endogenous factors (for example, the elements that a strategic narrative consists of, its "grammar" so to speak), but also pertain to the contextual setting as a bundle of exogenous factors that condition the effect this manufactured public opinion is able to exert on the actual political support and decision-making process. Our analysis is two-pronged. First, we treat public opinion as the dependent variable, conditional upon the key causal variable of narrative dominance. Using the Dutch mission in Uruzgan as a case study, we focus on the political communication of strategic narratives and counternarratives (and narrative dominance as the outcome of the sum of both) and their relationship to the level of Dutch domestic support. The second step entails teasing out the relation between domestic support and public opinion as the independent variable bearing upon final political consent for a given mission. We define this causality with the concept of "elite responsiveness."

\section{Strategic Narratives: "the grammar"}

Current literature on strategic narratives is built predominantly on constructivist ideas within IR, understanding power relations as socially constructed and constituted primarily by ideas and cultural context (Wendt 1992:93). Since the 1980s, 
scholars of various disciplines have paid increased attention to the role of narratives (Fischer 1984; Davis 2002). Since the invocation of the "narrative turn," narratives are examined not only as fixed and stable entities, but "rather as part of the complex and shifting terrain of meaning that makes up the social world" (Mumby 1993). Conceptually, narratives offer a structure "through which shared sense is achieved, representing a past, present and future, an obstacle and a desired end-point" (Miskimmon, O'Loughlin, and Roselle 2012). Strategic narratives are now understood as a resource for political actors to construct and communicate a shared meaning and to shape the perceptions, beliefs, and behavior of the public (Miskimmon et al. 2012). As such, Mumby argues that the "social construction of meaning is inevitably a political process" (1993). Based on the assumption that storytelling is the preferred sense-making currency of human relations, David Barry and Michael Elmes (1997) argue that strategic storytelling can serve to explain strategic issues in a more personal, meaningful way. Political actors can use narrative to give determined meaning to events and make them socially meaningful, in this way creating a certain perception of reality that facilitates their policymaking (Mattern Bially 2005:13, 107; Miskimmon et al. 2012).

The renowned political scientist and military historian Lawrence Freedman (2006) introduced the term "strategic narrative" to the realm of IR and strategic studies. According to Freedman, strategic narratives are deliberately constructed or reinforced out of ideas and thoughts that are already current. The heart of a government's military communication strategy is formed by a strategic narrative, "a compelling storyline which can explain events convincingly and from which inferences can be drawn." These narratives offer a way to frame issues and suggest responses. To be effective, they need to resonate with the values, interests, and prejudices of the intended audiences. Strategic narratives articulate end states and suggest how to get there. Hence, they help the public to understand the meaning of events related to the application of military force (Roselle 2010; Ringsmose and Børgesen 2011). These strategic narratives are per definition embedded within a national culture of norms, values, and attitudes regarding war and peace. By tuning in to these existing cultural predispositions, strategic narratives can serve to make sense of military incidents and to create public and political understanding, support, and legitimacy for a mission's purpose and relevance.

Of course, the question remains as to whether strategic narratives differ at all from sheer propaganda. Some argue that a fundamental confusion exists regarding the distinction between strategic narratives and actual policy (Michaels 2011:unpub. data). We hold the position that the art of crafting strategic narratives is much more than a PR-trick to "sell a war" or a mere tool for communication specialists. In a milieu of profligate media exposure and real-time communication, the importance of management by speech cannot be overrated. The "performative" aspects of framing interests and threats, formulating "mission statements," and establishing causality between ends and means is key to military and political strategy (de Graaf 2011). Strategic narratives are much more than labels for existing policy strategy; they develop in osmotic relationship to the formulation of political preferences, their implementation, and the actual development of operations on the ground. In many countries, the mobilization of resources and troops depends on some form of parliamentary support or political consensus, therefore, the way a policy argument is presented and put into a broader strategic context can become decisive in actually executing that policy. Hence, crafting a strategic narrative is inextricably part and parcel of the decision-making and implementation process, and thus, from a scholarly perspective, a key concept in any strategic studies approach. 


\section{Five "grammatical rules" for a Strong Narrative}

Ringsmose and Børgesen contend in a recent article (2011) in European Security that given similar challenges, similar threats, and similar international obligations, countries might arrive at totally different strategic narratives, and at greatly diverging political decisions regarding military deployment. This factual divergence of national positions in an identical international context demands further attention. Indeed, strong narratives might mitigate and deflect the negative impact of casualties and costs on public support for a mission, whereas weak narratives further undermine the public's willingness to continue in this fashion. Combining a number of recent studies on strategic narratives, a number of aspects can be identified that characterize a narrative as "strong" (Freedman 2006; Antoniades, O'Loughlin, and Miskimmon 2010; Roselle 2010; Voogd and Vos. 2010; Ringsmose and Børgesen 2011). We will refer to these elements as endogenous elements, or "the narrative's grammar," that influence the success and impact of a strategic narrative:

1. First, strong strategic narratives articulate a clear, realistic, and compelling mission purpose. It is paramount not to get entangled in subgoals or details, but keep the focus on long-term, overarching purposes and ambitions that at the same time have to be related to existing national interests, cultural norms, and values.

2. A second aspect pertains to legitimacy, in both an objective sense (judicial, procedural) and a subjective sense (political, public, ethical). This aspect dictates that a mission should not only be covered legally and that the decision-making process should be considered procedurally correct, but that it should also tune in to cultural and public norms and values and should be perceived as justified and legitimate by the public at large.

3. In the third place, a strong strategic narrative holds the promise of wartime success. The prospect of success directly triggers public support for a mission. A strategic narrative thus does not only have to include an overarching storyline, but should also project a horizon of success and progress.

4. In the fourth place, in order to be effective, a narrative should be presented in a consistent fashion. Persistent reinforcement of particular narratives by political elites, paired with real live events and media reporting those events, will increase the resistance to change the narrative (Baum and Groeling 2010). Thus, to frame this aspect the other way around, the absence of strong counternarratives will invigorate the existing official narrative; leading Ringsmose and Børgesen to conclude that strong strategic narratives depend on political consensus in a given country.

5. Finally, the strategic narrative must fit within an overall strategic communication plan, created at the highest level. It needs to be in harmony with the major national themes, ideas, images, and actions-both the spoken and unspoken ones. Strategic communication is not only about sending messages, but also about repeating and retelling them continuously, engaging in dialog, and building a net of relationships around them.

Despite these clearly formulated facets, it remains difficult to empirically map and gauge causal relations or mechanisms connecting increases or decreases of public support to the presentation of strategic narratives. Causal mechanisms between strategic narratives and public opinion are not easily identified, and until now, sound empirical evidence is seldom incorporated in the literature. We attempt to address this gap with our quantitative analysis as outlined below. We realize it is difficult to isolate strategic narratives as a key variable in explaining the level of public opinion. Concrete events, such as a steep increase in casualties, 
drastic changes in domestic security (for example, terrorist attacks taking place on the home front), or media reports of serious troop misconduct abroad (for example, the abuse of detainees), can sway public support significantly. Public opinion research remains a tricky business. As Pierre Rosanvallon (2008) argues, public opinion does not exist as such. Public opinion only takes shape when it is reflected in opinion polls, media coverage, interest groups, or collective action. The opinions of the public are nurtured and made manifest by specific agencies, for example, marketing companies and/or the media, by means of highly suggestive tools, whose results, in turn, inform public opinion and influence the way it is constructed (Rosanvallon 2008; Louw 2010:24). Notwithstanding these epistemological difficulties with the ambiguity and elusiveness of public opinion as a concept, we will endeavor to map the dynamics of the range of public support for the Dutch deployment in Uruzgan by zooming in on the way the Dutch government framed and crafted the mission. We will measure these official framing efforts against the five "grammatical rules" for a successful strategic narrative as set forth above, after which we proffer our quantitative analysis.

\section{Dutch Deployment in Uruzgan: The strategic narrative revisited}

Framing the war: clear and compelling mission purpose?

After the war in Afghanistan commenced in October 2001, the Netherlands contributed to various missions. After the 9/11 attacks, according to poll results of Gallup International, three-fourths of the Dutch public supported the American attack on Afghanistan. Moreover, the Dutch public also expressed its support for participation of Dutch troops therein (Goldsmith, Horiuchi, and Inoguchi 2005). When Dutch forces were actually deployed to Afghanistan as of December 2001, support remained stable throughout the next couple of years. However, from $2002 / 3$ onwards, the US "War on Terror" and the war in Iraq started to occasion serious controversy within Dutch society and its parliament.

The political debate about the Dutch government's decision to deploy a Special Forces Task Group in 2005-2006 to the southeastern border of Afghanistan as part of the US-led Operation Enduring Freedom (OEF) was a forerunner to subsequent debates about the mission to Uruzgan. From the beginning, rumors and misgivings about War on Terror abuses by US forces influenced the debate and course of action regarding the Dutch contribution to ISAF that commenced in 2006 (Dimitriu 2013). Within this politicized context, NATO requested the Dutch government to contribute to the expansion of the ISAF mission to southern Afghanistan early in 2005. Although hampered by doubts about possible public and political misgivings, the Ministries of Foreign Affairs and Defense agreed in the summer of 2005 to deploy a Task Force to the province of Uruzgan in the southern region of Afghanistan. The significance of this rather isolated area, with a population of 395,000 (mainly Pashtun), was mainly owing to the fact that it produced many Taliban leaders and that President Karzai picked the place to start his quest for power in late 2001.

In December 2005, just before the government was about to decide on the deployment, Boris Dittrich (leader of the political party Democrats 66) announced that his party (which was part of the Dutch coalition government at the time) would object to the decision to contribute to ISAF. His statement put the two D66 ministers in the Cabinet in an impossible position. They could not repudiate their party's position without severely compromising the government. Only after lengthy negotiations did the parliamentary D66 faction agree to accept a Cabinet statement (a so-called Article 100 letter) regarding its "intention" (rather than the "decision") to create a military mission to Uruzgan (Hazelbag 2009). When this Letter was presented to parliament on December 22, 2005, the seed of unrest 
regarding the meaning and implications of the stated "intention" was sown (Woordenspel Afghanistan 2006). Although two other opposition parties raised serious objections, a small majority eventually supported the decision. Coalition party D66 consented, but remained internally divided over the issue. On February 2, 2006 the Second Chamber ratified the decision to deploy Dutch soldiers under the flag of the Task Force Uruzgan (TFU) to the Uruzgan province in the south of Afghanistan. A few months later, the first Dutch troops of the Deployment Task Force (DTF) went to Uruzgan to prepare for the arrival of the main force that commenced its tasks on the first of August 2006.

The parliamentary decision was a brittle one. Most importantly, it still lacked a clear and compelling mission purpose, or an overall strategic communication plan. In their Article 100 Letter, the ministers involved, Henk Kamp (Defense), Ben Bot (Foreign Affairs), and Agnes van Ardenne (Development Cooperation), penned the basic elements of the strategic narrative: "The stabilization and reconstruction of Afghanistan, especially in the south, where the Taliban has its origin, is crucially important for promoting international order and for the fight against the international terrorism that also threatens Europe. In view of that importance, the government considers the risks [of the mission] acceptable" (Official Parliamentary Reports, no. 193). The mission's purpose was thus formulated as a loose combination of aspects: It was to bring stability, security, and reconstruction to the region, by increasing the local support for the Afghan authorities and by eroding support for the Taliban and affiliated groups, as preconditions for lasting development. The Ministers of Foreign Affairs, Development Cooperation, and Defense were realistic about the bad security situation. Dutch forces "need to take the possibility of attacks [of the insurgency] into accountwhile on patrol, during the logistical transport of goods in the air and on the ground, and on the bases of the ISAF units. Therefore, I cannot exclude the possibility that Dutch soldiers will fall victim during those operations" (Official Parliamentary Reports, no. 193).

This formula was broad enough to be amenable to all kinds of shifting interpretations. According to the Prime Minister, the Uruzgan mission resulted from "the conviction that the international community should not leave Afghanistan on its own" (NOVA 2005), indicating that the priority was with the Afghans in their battle against the Taliban. For the Minister of Defense, Henk Kamp, the mission's purpose mirrored the Dutch constitutional obligation to "contribute to more peace and security in the world" (NOVA 2005). But even before the mission had started, Kamp would add other dimensions to the strategic narrative. A couple of months later, Kamp explicated the overarching purpose of the mission by pointing to the necessity of fighting international terrorism, expressing loyalty to NATO, and advancing the UN's goals. During still other interviews he remarked that the Netherlands was there for the sake of the Afghan people, to help the international coalition, and to contribute to global security (NOVA 2005, 2006a,b).

In short, the strategic narrative subsumed a series of conflicting political intentions and inclinations. Ministers consequently juggled with the four overarching goals mentioned above: Sometimes they stressed the necessity to fight terrorism as part of the global war against international terrorism. Sometimes they focused more on domestic security (fighting terrorists in Afghanistan to prevent them from coming to the Netherlands) or on loyalty to NATO. On other occasions, ministers defended the mission with humanitarian arguments, explaining that it would make life better for the Afghans (Ministry of Defense 2006; Klep 2011:34, 126).

The lack of clarity and consistency in the government's strategic narrative is logged in the media reports. Over the years, newspapers portrayed the purpose of the mission in various ways-alternately highlighting humanitarian aspects, 
international loyalties, and security issues. Analysis of our data set of 4,000 newspaper articles on the Uruzgan mission between 2006 and 2010 (see below) generated six different "media frames"; these each being a simplified and reiterated representation and interpretation, in which the military mission was cast and that served as the "building blocks" for the strategic narratives regarding the use of force. Namely: (i) Dutch soldiers are conducting an "ink spot" approach to securing the region; (ii) a "3D" approach that focused on Defense, Development, and Diplomacy; (iii) a mission of reconstruction; (iv) a hybrid mission, combining stability, security, good governance, and reconstruction (the Article 100 Letter); (v) an elusive, so-called Dutch Approach (Brocades Zaalberg 2013); and (vi) a counterinsurgency mission. Each of these frames consisted of a different mix of military, civilian, and/or humanitarian elements.

\begin{tabular}{lcccccc}
\hline Media frames & $\begin{array}{c}\text { Ink spot } \\
\text { approach }\end{array}$ & 3D & Reconstruction & $\begin{array}{c}\text { Article } \\
100 \\
\text { Letter }\end{array}$ & $\begin{array}{c}\text { Dutch } \\
\text { approach }\end{array}$ & Counterinsurgency \\
\hline $\begin{array}{c}\text { Total data points: } \\
\text { (July 2006- } \\
\text { January 2009) }\end{array}$ & $159(31 \%)$ & $71(14 \%)$ & $184(36 \%)$ & $33(6 \%)$ & $50(10 \%)$ & $15(3 \%)$ \\
\hline
\end{tabular}

(Notes. Media frames of the approach of the Task Force Uruzgan July 2006-January 2009).

Given the already low endorsement rates in the Netherlands for the military operations related to the War on Terror (Iraq and Afghanistan), it comes as no surprise that the Dutch public was not easily convinced by these overlapping, vague, and even contradictory descriptions of the mission's purpose.

\section{Legitimacy}

This lack of a clearly formulated mission statement had serious consequences for the public and political sense of the mission's legitimacy. Legitimation is understood as a process of normative evaluation from which the "ascribed quality of legitimacy" emerges (Berger 1966:112; Parkinson 2003:184). Within the discourse on military missions, three strands of legitimacy can be discerned: the international legality of the mission, the perceived legitimacy of the process of national decision making, and the perceived justness and necessity of the intervention. Within the Dutch public and parliamentary discourse, international legitimacy and legality were the most important aspects. Everts (2008) argues that since the 1990s these two elements count as preconditions for garnering public support for any military mission. Prior to the intervention in Iraq, for example, the level of public support was closely connected to the question of whether the United States would achieve UN approval for its "pre-emptive strike" (Everts 2008). The strategic narrative regarding the TFU thus wisely included explicit references to the international agreements, conferences, commitments, and legal principles provided by the UN and NATO.

However, the strategic narrative failed to provide compelling arguments to underscore the procedural legitimacy of the domestic decision-making process. Although Prime Minister Jan Peter Balkenende and Defense Minister Henk Kamp repeatedly claimed that they arrived at a thorough and deliberate decision based on in-depth analyses and military advice, their credibility was already low from the get-go. Coalition party D66 together with some parties in the opposition used the Article 100 procedure to assert their objections to both the deployment decision as such and the alleged obfuscated decision-making process. They criticized the fact that the official announcement of the government's investigation 
into the possibilities of a military mission in southern Afghanistan in 2005 had been tucked away in a report on a totally different subject (Hazelbag 2009). Accusations of nontransparency and even deception kept recurring. Opposition parties, commentators, and journalists kept repeating the argument that the government had bypassed correct procedures, had held back information pointing to the military risks, and had kept secret the requests from NATO and coalition forces to step up and prolong the TFU (Hofland 2010).

Doubts about the legitimacy of the mission's purpose-the third strand in the legitimacy debate-were also present at the start of the debate. The ISAF mission in Uruzgan was launched against the background of recurrent revelations about human rights abuses in Bagram, Abu Ghraib, and Guantanamo Bay. Commentators questioned how the Dutch armed forces could be so sure that similar incidents would not occur under their auspices. TFU's legitimacy was further tainted by its proximity to the US-led Operation Enduring Freedom (Official Parliamentary Reports, no. 201). Opposition leaders, notably Jan Marijnissen (Socialist Party), contended that the Netherlands allowed itself to be treated as a stooge of the United States. The legitimacy argument thus reinvigorated the "fight or reconstruct" debate and eroded the government's strategic narrative. An opinion poll of the German Marshall Fund of the United States and the Compagnia di San Paolo (2007) indicated that 86 percent of the Dutch citizens interviewed supported reconstruction efforts in Afghanistan, while only 46 percent supported combat missions in that country.

\section{Prospect of success}

Closely related to formulating clear and compelling mission purposes and soliciting legitimacy is the importance of depicting a realistic prospect for success. Without clearly formulated policy goals at the start, it is quite cumbersome to design them once the mission is underway. Be that as it may, at no point during the first years of the mission did the government present explicit examples of measured success to the public. Members of the political elite, ministers, and military commanders kept stating that TFU had made "improvements," but that success was very hard to quantify. Minister Kamp stated, for example, that only subsequent to the mission's completion "visual results could be an improvement of the quality of provincial governance, better functioning police forces, and a more effective Afghan National Army" (Official Parliamentary Reports, no. 201).

Some attempts to formulate a prospect of success were made, however. For example, directly after the mission deployed in August 2006, TFU commanders introduced the so-called oil stain approach or ink spot approach to the Dutch public at home, to describe the way their troops went about securing the region (Official Parliamentary Reports, no. 226). This military frame became a real catchphrase: The ink spot could be mapped, geographically, it could be presented on maps and charts on television, and any increases and extensions or even fusions of secured "ink spots" in Uruzgan could be easily demonstrated. However, this metaphor soon lost its persuasive power, since it was merely a tactical, military argument rather than a full-fledged policy goal.

Next, at the end of 2006, a rather impressionistic approach to assessing success was introduced when the Dutch government started using the so-called 3D approach, referring to the comprehensive combination of Defense, Diplomacy, and Development (Official Parliamentary Reports, no. 247). While the terminology was already being used by other countries as well (in the United States and UK), the Dutch government presented the "3D approach" as a Dutch invention (Official Parliamentary Reports, no. 279). Success was now reframed: Rather than pointing to progress on the battlefield, it was to be found in the fact that the Dutch counterinsurgency approach made an impression on other ISAF countries, 
including the United States, and that the old adage of the Netherlands as a "pilot country" on the international diplomatic scene was being revitalized through this sophisticated and novel approach in Uruzgan.

In the media, some pointed out that Dutch soldiers used bicycles and carried their guns on their backs, or even walked the alleyways and streets in Uruzgan; as compared to the Americans who only showed themselves in heavily armored vehicles, with weapons ready, and who spoke with guns rather than by having tea with Afghan elders. Other rather successful but incidental efforts to narrate successes achieved in Afghanistan pointed to the fact that "Tarin Kowt's streets were lit again at night." Used by different TFU commanders, by defense chief General van Uhm, as well as by Minister of Defense Eimert van Middelkoop (who was Kamp's successor), this narrative was repeatedly used to illustrate the claim that the Dutch forces were having success in bringing stability and development (Toespraak van de Commandant der Strijdkrachten 2008).

Although the 3D concept, and the above-mentioned illustrations, certainly had some communicative impact, they still did not solve the underlying problem-the lack of a clear strategic narrative or prospect of measurable success. The $3 \mathrm{D}$ concept was as vague and open for multiple interpretations as the original mission statement had been (Van der Lijn 2011). The Advisory Council for International Affairs (Adviesraad Internationale Vraagstukken-AIV) therefore concluded that the government was still obfuscating a clear view on the purported end state of the mission (AIV 2009; Dimitriu and de Graaf 2010), and other than haphazardly trying to infuse some optimism in the public's spirit was therefore not able to create sustainable support.

\section{The absence or presence of strong counternarratives}

Arguably the most important endogenous factor eroding popular support was the clatter caused by counternarratives to the mission that were increasingly evident in the media. As scholars have argued before, a highly relevant aspect for creating and sustaining public support for the use of force is elite consensus. The media's reaction to policy decisions is dependent on the level of agreement among politicians (Entman 2007; Baum and Groeling 2010). The greater the dissent, the better the possibility that the media will start inscribing these political dissenting voices, that is, counternarratives, into their dichotomous media frames.

Indeed, immediately after the reception of the Article 100 Letter in Parliament, in December 2005, political polarization about the nature of the mission erupted-and was reinforced and dramatized in the media. The opposition-including the socialist SP and left-liberal GroenLinks partiestogether with members of the governing D66-party fired their rounds on February 2, 2006, by claiming that Task Force Uruzgan would be a "combat mission" and a "war operation" rather than the supposed "reconstruction mission" (Official Parliamentary Reports, no. 207). The dichotomy that was used initially to indicate the differences between OEF and ISAF was now used to frame the Dutch deployment to Uruzgan. These descriptors were soon taken up by other opposition parties as well (such as the Socialist Party and Geert Wilders' far right party), thereby introducing the counternarrative of the "combat mission intentionally disguised as reconstruction mission" (Official Parliamentary Reports, no. 79:222).

The progressive parties' major argument for criticizing TFU as a "combat mission in disguise" was provided by the threat of "mission creep" and an overlap with the American military's Operation Enduring Freedom. This proximity could impinge on the TFU's reconstruction activities, which-in their view-lay at the heart of the mission's purpose. Minister Ben Bot (Foreign Affairs) and Minister 
Eimert van Middelkoop (Defense) tried to turn the tide by pointing out that such a simple dichotomy did not do any justice to the reality on the ground (Official Parliamentary Reports, no. 222). The armed forces themselves tried to avoid this dichotomous scheme as well, by pointing out that their operations served multiple ends (Dam and de Vreij 2006; Koelé 2006; Van Griensven 2007). But the harm was already done; the fighting/reconstructing dichotomy was there to stay, both in parliament and in the media (Van Reijn 2007).

\section{Strategic Communication plan}

Although the ministries of Foreign Affairs, Development Cooperation, and Defense were aware of the importance of public support, they did not draft a strategic communication plan nor did they explicitly deploy a strategic narrative. No central direction or coordination of the communication policy existed. After Parliament approved the mission in February 2006, the central government lost interest in maintaining political and public support for the mission and left it to the Ministry of Defense to pick up on the PR front.

As a result, as soon as the opposition started to sow doubt as to the purpose and success of the mission, the government was on the defensive. The Ministry of Defense (until 2008 acting on its own behalf, rather than operating jointly with the other ministers involved) kept rehearsing the argument that the complex operations in Afghanistan could not be simplified to a "combat mission" or a "reconstruction mission." In fact, the Ministry of Defense never tried to mitigate or tone down the mission's true risks or military efforts. However, compared to the opposition and media frame of the "reconstruction mission gone awry," the strategic narrative, as put forward in the Article 100 Letter, lacked robustness, was not supported by other ministers, and was not media savvy enough. Throughout the mission, despite the decrease of public support and the repeated recommendations of military leaders to improve the image of the mission, there was insufficient political engagement directed toward the strategic communication process. In the end, it was not the (indistinct) strategic narrative on the multifunctional mission that came to dominate public debate, but the clear-cut and critical counternarrative.

\section{A Quantitative Analysis of the Nexus between Strategic Narratives and Public Opinion}

In our discussion of the political decision-making process and various public reactions to the mission, we have argued that the Dutch government lacked a strategic communication plan, that the mission's purpose was not formulated clearly enough, and that legitimacy became a bone of contention. Contrary to scholarly research that explains diminishing public support by pointing to the number of casualties or injured soldiers, we did not see such a mechanism at work in the Netherlands. Public support for the mission did not decrease when casualties were reported in the media (Everts 2008; Van der Meulen and Vos 2008). We have suggested that the lack of public support might well be tied to the absence of an effective strategic narrative, combined with the emergence of strong and compelling counternarratives, as described above. Given our qualitative discussion of the status of these strategic narratives, we now proceed to further gauge the nexus (or the lack thereof) between these narratives and the waning of public support.

We tested our hunch by analyzing a data set composed of more than 4,000 clippings drawn from all of the national newspaper reports and from articles in major magazines regarding the TFU between July 2006 and January 2009. We coded 
them using five categories: (i) reference (direct or indirect phrasing) to the official narrative regarding the TFU, (ii) the presence of a counternarrative, (iii) officials reiterating (parts of) the counternarrative, (iv) officials rejecting, but explicitly mentioning the counternarrative, and (v) inconclusive reporting. (The latter reports were not used in the coding process and removed from the corpus.) Thus, we validated any mention of the TFU as either supportive of the governmental strategic narrative, or directed against it; using the inconclusive category to catch the remainder. The official strategic narratives and counternarratives were identified through a qualitative study of governmental documents, public press releases, and speeches issued within the time frame outlined in the qualitative paragraph.

A positive coding for the presence of a supportive narrative could be:

1. "We are in Uruzgan to bring stability and reconstruction in order to prevent international terrorism from coming to Europe."

A positive result for a counternarrative could be:

2. "While the government presented the mission as a reconstruction mission, the heavy combat and casualties make clear we are in a combat mission."

However, counternarratives could also unwittingly be reinforced by governmental utterings, for example, when officials or politicians inadvertently appropriated and supported oppositional or media criticisms by stating:

3. "We build where we can, we fight where we must." (Hence, reiterating the dichotomy between fighting and reconstructing.)

Or by military officials explaining the mission in the following way:

4. "While the media continuously focus on the fighting aspects of the mission, I want to let you know that we also have made progress in our reconstruction efforts."

\begin{tabular}{lll}
\hline Narrative identified (example) & Labeled as & Coded \\
\hline $\begin{array}{l}\text { "We are in Uruzgan to bring stability and } \\
\text { reconstruction in order to prevent in- } \\
\text { ternational terrorism from coming to }\end{array}$ & $\begin{array}{c}\text { Official presentation of strategic } \\
\text { narrative }\end{array}$ \\
$\begin{array}{l}\text { Europe." } \\
\text { "While the government presented the }\end{array}$ & Presence of counternarrative \\
mission as a reconstruction mission, & \\
the heavy combat and casualties make & \\
clear we are in a combat mission." & \\
"We build where we can, we fight where & Counternarrative reinforced by \\
we must." & governmental utterings \\
"While the media continuously focus on & Defensive posture against counter- \\
the fighting aspects of the mission, I & narrative, while thereby reiterat- \\
want to let you know that we also have & ing it \\
made progress in our reconstruction & \\
efforts." & \\
\hline
\end{tabular}

We then counted the results, based on the coding, while accepting that more than one narrative could be identified in a single article. We did so on a monthly basis. See the table below for an example of the first 4 months. 


\begin{tabular}{lllll}
\hline Date & $\begin{array}{l}\text { Strategic } \\
\text { Narrative (1) }\end{array}$ & $\begin{array}{l}\text { Counternarrative } \\
(2)\end{array}$ & $\begin{array}{l}\text { Reinforcing the } \\
\text { counternarrative (3) }\end{array}$ & $\begin{array}{l}\text { Explicitly rejecting } \\
\text { the counternarrative (4) }\end{array}$ \\
\hline August 2006 & 4 & 10 & 1 & 7 \\
September 2006 & 4 & 11 & 2 & 1 \\
October 2006 & 0 & 8 & 2 & 12 \\
November 2006 & 3 & 19 & 2 & 13 \\
\hline
\end{tabular}

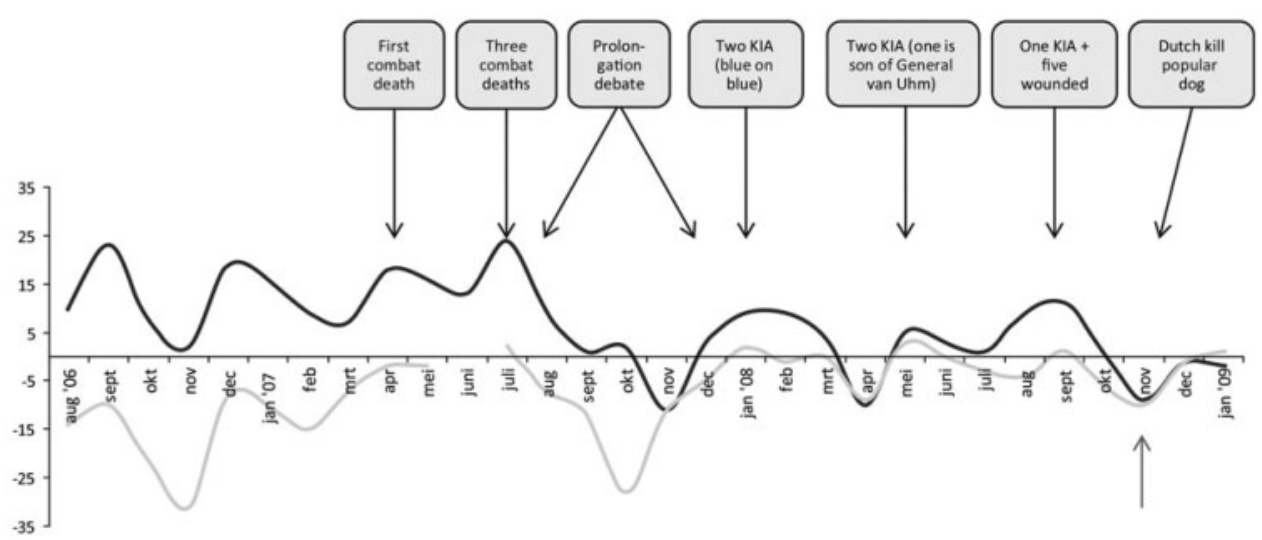

Dutch public support ——Narrative dominance (absolute) $\quad \uparrow \begin{aligned} & \text { Less accurate } \\ & \text { mesasurement }\end{aligned}$

Fig 1. Correlation Narratives and Public Support

Results were plotted against monthly opinion polls conducted by the Dutch Centre for Behavioral Sciences. In this way, the nexus between narratives and public opinion could be established accurately.

Based on the above explanations, we consider both type (3) and (4) narratives as supporting the counternarrative; for even in negating or rejecting a frame, it is explicitly repeated and disseminated in public. Narrative dominance was defined as the sum of (1) minus (2, 3, and 4). Subsequently, a graph could be sketched, relating narrative to the level of public support for the mission. (Figure 1).

Our results indicate that throughout the mission, counternarratives had the upper hand (graphically depicted on the negative axis of narrative dominance). A correlation emerges from this graph that points to an initial (tentative) but important conclusion: The strategic narratives and counternarratives crafted by politicians (proponents and opponents) do indeed shape public opinion. In this case, as counternarratives mounted, narrative dominance plummeted, and public support for the mission eroded.

Secondly, it is also evident that combat deaths as such did not cause a decrease in public support. On the contrary, lethal incidents seemed to have caused a temporary increase in both the number of strategic narratives presented in the media and the level of public support-indicating some evidence for the rally-aroundthe-flag phenomenon. Neither the media nor the opposition parties were apparently willing to level criticisms against the mission or the government immediately after soldiers were killed. Combat deaths only seem to play a role inasmuch as they can be considered "relative dramatic events." For example, the first reports on Dutch firefights in July 2006 led to extensive media coverage, while similar 
events attracted hardly any attention at all anymore in 2008. The same holds true for the first combat deaths; after a steady occurrence of battle deaths, casualties gradually become less salient. Incidents thus only gain in newsworthiness if they contain more dramatic and/or personal features, exemplified in the "blue on blue" event in January 2008, or the battle death of Lieutenant Dennis van Uhm, son of Commander of the Armed Forces General Peter van Uhm, in May of that same year.

In the long run, however, dramatic events do gain salience: They are taken up and reiterated in political debates and public discussions, especially when the mission is evaluated in the media, which occurred primarily when units were rotated or prolonging the mission was up for debate. During these debates, journalists, opinion makers, and politicians reflected on the mission and engaged in cost-benefit analyses: The costs of the mission (with fatalities as key costs) were weighed and considered against its purported benefits (the aim and the results). This process of assessing the relative value of a mission occurs via the means of the media frames available, that is, through the lens of the dominant narrative. If enough counternarratives have been imprinted and inscribed in the public's political collective memory, they will serve to erode public support and push the balance in a negative direction-all the more so when the official narrative is less than robust.

Hence, of all the endogenous elements that constitute a successful strategic narrative, we conclude that the presence of persisting counternarratives is a key variable in understanding the waning public support for the military mission in this case study. Our research was unable to document direct, more objective links between the public's preferences and variables such as rising costs or the length and effectiveness of the mission. Even when numbers are to be had in this regard, these objective variables beg interpretation-they have to be made to mean something. As Baum and Groeling, among others, have pointed out, a public rarely observes foreign policy directly. It rather reacts and responds to the government's and the media's re-presentation of events (Berinsky 2009; Baum and Groeling 2010). So too, these representations are never discussed in a vacuum but always debated in conjunction with the level of success, the purpose, and the legitimacy of the mission as communicated by means of strategic narratives. This corresponds with the scholarly consensus that the more the public views the military mission to be vital, the higher the price the public is willing to pay to achieve the foreign policy goal (Gelpi et al. 2009:11). In the Dutch case, the problem was that two of the ruling coalition partners favored the mission, but they were not able to present compelling strategic narratives in order to explain the costs and combat deaths to the public. The feeble attempts that were undertaken to shore up support were undermined by coalition rivalry and vociferous opposition in parliament.

\section{"Elite Responsiveness" to Negative Narrative Dominance and Dwindling Public Support}

Now, to what extent does such a negative narrative dominance and ensuing breakdown in public support matter in the process of decision making? To answer this question, we need to gain a better understanding of the elite responsiveness to public opinion developments (Page and Shapiro 1983; Kreps 2010). The constraining effects of public opinion and of public preferences on the use of military force have been examined extensively (Holsti 1992, 2004; Sobel 1993; Zaller 1994). Matthew Baum (2004) has argued that an attentive public can inhibit democratic state leaders from risky foreign policy initiatives, including military interventions (see also Knecht and Weatherford 2006). Foyle (1999), Knecht and Weatherford (2006) maintain that public preferences do not directly translate 
into policy outcomes, but are mediated through state leaders' beliefs regarding the impact that public opinion should have on foreign policymaking. According to Kreps, in situations of strong elite consensus, public opinion might well have very little impact on state leaders' decisions (2010; see also Dimitriu 2012). Justin Massie (this issue) also demonstrates how a broad elite consensus was "instrumental to the government's ability to overcome the mounting public opposition to the war and to prolong for two years Canada's combat role in Kandahar." Elite consensus is thus a stark explanatory factor in establishing the impact of narrative dominance and public opinion on political decision making. This influence is hard to approach from a perspective of causality, since the decision-making process is not one-directional but should rather be understood as a reciprocal or interactive relationship between public opinion and policymakers (Zaller 1994; Wlezien 1996; Jacobs and Shapiro 2000; Holsti 2004; Hobolt and Klemmensen 2005). While elites shape public opinion, they are at the same time being responsive to it. Elite responsiveness differs across time and place and depends on the issue at stake (Hobolt and Klemmensen 2008). Therefore, elite responsiveness should be understood as the complex outcome of structural characteristics of a given political system and polity, combined with the contingency of incidents and other happenstances.

For the situation in the Netherlands, the decrease in public support owing in large part to the government's lack of narrative dominance directly translated into the decision-making process. This direct effect is not discernible in other countries, such as Denmark or Germany. Therefore, we will conclude our line of argument by briefly elaborating on the factor of elite responsiveness in the Netherlands in order to explain how the disintegration of public support came to bear on the government's decision to abort the TFU. As stated above, outspoken public opinion does not automatically mobilize an elite's response. We argue that the degree of elite responsiveness is conditioned by (i) the military culture and the historical repertoires of military actions in the collective memory, (ii) the makeup of the political system, (iii) the media landscape, (iv) the international context, and (v) the reality of the battlefield.

\section{Military culture and historical repertoires of military actions}

Decision making on military missions does not take place against a historical $t a$ bula rasa. Elite responsiveness is higher when previous military experiences have sensitized public opinion to issues of legality and legitimacy. In the Netherlands, the Srebrenica debacle in 1995, when Bosnian Serbs killed thousands of Bosnian Muslims after Dutch UN peacekeepers had left the enclave, profoundly shook the country and prompted intense public debate on the purpose and feasibility of peacekeeping missions as such. According to military historian Christ Klep, a "post-Srebrenica-realism" set in, resulting in far more reluctant decision-making processes vis-à-vis military missions (Klep and van Gils 2005:359-386). After the Srebrenica debacle, the Dutch government felt strongly that they needed to work hard at presenting themselves once again as a trustworthy partner and ally-an inclination induced by the fact that, as a relatively small country, the only way of gaining influence and leverage is by actively participating in international coalitions (Davids Commission 2010). Others also suggest that after the Dutch experiences in Srebrenica a version of the "rally-round-the-flag" phenomenon might be at work (Everts 2008:123). Generally, a majority of the population expresses a passive but stable concern about security issues, particularly in conjunction with human security and humanitarian concerns (Everts 2008). Dutch military culture is nevertheless not very robust. In recent years, the Dutch population has not shown much interest in foreign policy. Other matters, such as education, criminality, and healthcare are more of a concern. Research shows that Dutch foreign policy, 
such as troop deployment and development aid, has the lowest priority among government issues for the Dutch population (Van der Leij 2009). Furthermore, the Dutch population seldom believe that Dutch missions serve any collective or personal gain, such as increased national security (Ministry of General Affairs 2006).

\section{The political system}

Official strategic narratives do not operate in a societal or political vacuum. The effect of the dynamic relation between narrative dominance and public opinion on elite responsiveness is heavily influenced and conditioned by the level of autonomy a national government enjoys when it comes to military operations within its political system. In the Netherlands, the prerogatives of the government, not to mention those of the Prime Minister, are severely impeded by the presence of a consensual democracy and representative majority.

The Dutch system is a rather extreme form of representative democracy. Its high district magnitude and low threshold results in a large number of political parties represented in parliament-hence the need for coalition governments. In addition, there is the consensus-oriented tradition in decision making. The result is governments (executive) that are continually accountable to parliament and, more indirectly, to public opinion. Moreover, the Dutch Prime Minister has no overriding executive powers regarding issues of foreign affairs or security policy. He has no "Richtlinienkompetenz" like the German chancellor and counts as "primus inter pares" among his ministers. Thus, the principle of departmental autonomy dictates that in order for the Prime Minister or the government coalition as a whole to arrive at a conclusion, compromises between the various ministers involved are inevitable. These ministers may represent a number of different political parties each of which strive to have a voice in the decision-making process-in order to satisfy and pacify the respective constituencies they will face in the next elections. Military operations thus easily become subject to the pressures of political profiling by individual political parties or ministers within the government coalition. Vote seeking and party-political motivations can be the dominant factor in political positioning; some prominent Dutch politicians and military leaders believe that that was behind what D66 did during the decision-making process around Uruzgan (Brinkel, Moelker, and Westmaas 2009).

Furthermore, since the Sebrenica debacle in 1995, the influence of Parliament on the decision-making process has significantly increased, leading to parliamentarian micromanagement and difficulties for any government to act according to its ambitions (Noll and Moelker 2013:260-61). To summarize this important condition in one line: It might be true that fighting COIN (and launching strong narratives to support this fight) as a representative democracy with a multiparty system is a contradictio in terminis.

\section{The media landscape}

Public sentiment often does not sway politicians directly, but media framing does act as an intermediate force. Due to mechanisms of "medialogics" and the inclination to act as "watchdogs," journalists tend to simplify the news, adapt and abbreviate statements to fit in with existing patterns and frames, and will-because of their dramatic power and newsworthiness-tend to concentrate more on critical comments, counternarratives, and incidents rather than complacently copy-paste official statements on a mission into their reports and broadcasting. This argument holds some import because the general public usually digests "news" on 
military operations in a rather passive fashion, and bases its judgment on general media headlines without spending a lot of time and energy on retrieving all of the official details on a specific policy (Lau and Redlawsk 1997; Lupia and McCubbins 1998). In the Netherlands, newspaper headlines reinforced the fighting-reconstructing dichotomy, leaving out all of the other complex considerations at stake. Only a few exceptional journalists tried to step out of this frame. Joeri Boom, for example, questioned: "Why does the Ministry of Defense [accept these false judgments, and] not refer to the excellent Article 100 Letter instead?" (Boom 2007; see also: De Vreij 2008). Such negative media frames were reinforced by persistent inter-coalition bickering and numerous politicians in the opposition who adopted the TFU debate to attack the already weakened coalition.

\section{International context}

Elite responsiveness to public criticism on military operations in a small, internationally allied country as the Netherlands likewise depends frankly on the international context. Governments of small, pro-Atlantic countries may reach consensus to persist in continued troop contribution to international missions despite public sentiment. The shared understanding among elites as to the prime national goals was a reason for Canadian politicians to remain united in their decision to maintain the force level in Afghanistan, despite obscure direct national interest and vocal public opposition (Kreps 2010; Massie, this issue). Also, debates occurring in other NATO countries on increasing troop numbers may impact national debates. However, throughout the recent course of Dutch history, the political cohesion on international issues has been far from evident.

The Dutch stance against Atlantic policy manifested itself clearly when the United States started Operation Iraqi Freedom in 2003-support for the "War on Terror" soon gave way to serious misgivings. In line with most other European countries, the Dutch public was predominantly against the US invasion of Iraq. One of the main reasons for the lack of support was the absence of any form of international agreement or UN convention underpinning this intervention (Everts 2008). The Dutch contribution to the Stabilization Force Iraq (SFIR) could however count on a modest level of public support, but public opinion did not really warm to the Iraqi War (Davids Commission 2010:65-67). Public sentiment was echoed in political debates. Moreover, the Iraq debacle, the absence of WMD and simultaneous revelations about human rights abuses, spilled over into the decision-making process regarding the mission in Uruzgan, dividing political parties from the outset on that mission as well. Moreover, revelations of secret government support for the US-led war in Iraq in January 2010, by the independent commission Davids, further troubled relations between the two governing parties, CDA and PvdA, and marked the beginning of the end for the coalition and therefore heightened elite responsiveness to public criticism once again.

\section{Reality of the Battle field: narrative alignment}

It hardly needs to be said that developments "on the ground," on the battlefield, cannot be narrated away indefinitely. As the real story unfolds, it still needs to resonate with the presupposed narrative in order to produce narrative alignment. Elite responsiveness to public support is also conditioned by the degree of consistency between the strategic narrative and the reality of the battlefield. Cognitive dissonance can only be sustained so long. Formulating a broad and ambiguous mission might make sense because then all parties can claim that their interests are represented in the mission (Stone 2011), and as such increase elite consensus. 
In this case, both the Cabinet as well as the largest opposition party (PvdA) could claim victory to their electorate. But in the end the strategic narrative needs to be able to capture a variety of scenarios on the battlefield in order to maintain credibility among the public as well as with oppositional parties. As Baum and Groeling convincingly argue (2010:209, 221-22), the media and the public will increasingly become aware of the reality on the ground during the course of a conflict. Ambiguity might well serve the initial acceptance of a policy decision regarding sensitive issues, such as the use of force within the context of a fragmented political system, but the public will undoubtedly discard this veil of ambiguity when the reality on the ground appears to be far from ambiguous. And in conjunction with the other factors above, elite responsiveness may increase correspondingly.

\section{Conclusions}

We have sought to add some empirical research to the growing literature on the nexus of public opinion, strategic narrative, and the use of force. Based on our findings, we conclude that the elements necessary for a convincing strategic narrative were severely lacking in the case of the Dutch deployment to Uruzgan. Moreover, it was not the strategic narrative, but the counternarrative of the "combat mission disguised as reconstruction mission" that came to dominate the national debates. By means of these frames, and not the official statements, the counternarratives gained prominence over the course of the years 2006-2010.

Secondly, the empirical data we gathered suggests that the level of public support follows narrative dominance and that there is a correlation between narrative dominance and public opinion. Public opinion indeed depends on the strategic narratives formulated, but only when seen in conjunction with the counternarratives produced by opposing parties.

Thirdly, we conclude that in trying to craft coherent strategic narratives and to control the emergence or dominance of counternarratives, governments are conditioned by their level of autonomy and corresponding elite responsiveness. Given the system of consensual democracy and representative majority and the Prime Minister's lack of overriding executive power, the positional power of the Dutch government with regard to the use of force was low. While declining public support (as provoked by weak narratives, or strong counternarratives) does not translate directly into elite dissent or the loss of political support, let alone to a government's demise, it might precipitate already existing cleavages within a multiparty, consensual system such as the Dutch one.

More research is necessary to understand how elite responsiveness is conditioned by public skepticism about troop deployment in a specific country. But more insight into the power of counternarratives and their effects on elite consensus is crucial for NATO as an alliance. So too, raising support for complex, lengthy, and burdensome counterinsurgency operations or other expeditionary missions may prove to be(come) an insurmountable barrier in countries that lack a homogeneous party system and where the public attaches great value to issues of mission purpose, prospects of success, legitimacy, and legality. The Dutch case testifies to this point.

\section{References}

Adviesraad Internationale Vraagstukken (AIV) [Advisory Council of International Affairs]. (2009) Crisisbeheersingsoperaties In Fragiele Staten, De Noodzaak Van Een Samenhangende Aanpak. Den Haag: AIV. [Crisis control operations in fragile states. The necessity of a comprehensive approach] Almond, Gabriel. (1950) The American People and Foreign Policy. New York: Praeger. 
Antoniades, Andreas, Ben O’Loughlin, and Alister Miskimmon. (2010) Great Power Politics and Strategic Narratives. Working Paper No. 7, The Centre for Global Political Economy, University of Sussex.

Arquilla, John, and David Ronfeldt, eds. (2001) Networks and Netwars: The Future of Terror, Crime, and Militancy. Santa Monica, CA: RAND Corporation.

Barry, David, and Michael Elmes. (1997) Strategy Retold: Towards a Narrative View of Strategic Discourse. Academy of Management Review 22 (2): 429-452.

Baum, Matthew A. (2004) How Public Opinion Constrains the Use of Force: The Case of Operation Restore Hope. Presidential Studies Quarterly 34: 187-226.

Baum, Matthew A., and Tim J. Groeling. (2010) War Stories: The Causes and Consequences of Public Views of War. Princeton: Princeton University Press.

Berger, Peter L., and Thomas Luckmann, eds. (1966) The Social Construction of Reality. New York: Doubleday.

Berinsky, Adam J. (2009) In Time of War: Understanding American Public Opinion from World War II to Iraq. Chicago: University of Chicago Press.

Boom, Joeri. (August 10, 2007) De Weg Naar de Hel is Geplaveid Met Goede Bedoelingen. De Groene Amsterdammer. Available at www.groene.nl. (Accessed May 12, 2013.)

Brinkel, Theo, René Moelker, and Sanne Westmaas. (2009) Politiek-militaire betrekkingen, Recente ontwikkelingen met betrekking tot het primaat van de politiek. [Politico-military relations. Recent developments regarding the primacy of politics]. In Krijgsmacht en samenleving, Over de bestuurlijke inzet van een geweldsinstrument: bestuurlijke, politieke en veiligheidsaspecten, edited by René Moelker, Jörg Noll, and Michiel Weger de. Breda: Boom, 163-189.

Brocades ZaAlberg, Thijs W. (2013) The Use and Abuse of the Dutch Approach to Counterinsurgency. Journal of Strategic Studies 36 (6): 867-897.

Brody, Richard A. (1991) Assessing the President: The Media, elite Opinion and Public Support. Stanford: Stanford University Press.

Commissie van onderzoek besluitvorming Irak "Davids Commission." (2010) Rapport Commissie van onderzoek besluitvorming Irak. Amsterdam: Boom. [Report by the Committee to Investigate DecisionMaking concerning Iraq]

Dam, Bette, and Hans Vreij De. (October 31, 2006) Nederlands NAVO-Commando Zuid- Afghanistan, 'Geen Schoolplein Waar je vervelende Kinderen Wegjaagt'. Wereldomroep. Available at www.rnw.nl. (Accessed February 11, 2013.)

DAvis, Joseph E. (2002) Narrative and Social Movements: The Power of Stories. In Stories of Change: Narrative and Social Movements, edited by Joseph E. Davis. New York, NY: State University of New York Press.

De Vreij, Hans. (July 27, 2008) Over een Enquête En Een Wederopbouwmissie. Wereldomroep. Available at www.blogs.rnw.nl. (Accessed August 28, 2013.)

Dimitriu, George R. (2012) Winning the Story War: Strategic Communication and the Conflict in Afghanistan. Public Relations Review 38: 195-207.

Dimitriu, George R. (2013) Interrogation, Coercion and Torture: Dutch Debates and Experiences after 9/11. Intelligence and National Security 28: 547-565.

Dimitriu, George R., and Beatrice de Graaf. (2010) The Dutch COIN Approach: Three Years in Uruzgan, 2006-2009. Small Wars Eं Insurgencies 21: 429-458.

Entman, Robert M. (2007) Framing Bias: Media and the Distribution of Power. Journal of Communication 57: 163-173.

Everts, Philip. (2008) De Nederlanders en de wereld, Publieke opinies na de Koude Oorlog. Assen: Van Gorcum.

Fischer, Walter R. (1984) Narration as a Human Communication Paradigm: The Case of Public moral Argument. Communication Monographs 51: 1-22.

Foyle, Douglas C. (1999) Counting the Public In: Presidents, Public Opinion, and Foreign Policy. New York: Columbia University Press.

Freedman, Lawrence (2006) The Transformation of Strategic Affairs. London: Routledge.

Gelpi, Christopher, Peter D. Feaver, and Jason Reifler. (2009) Paying the Human Costs of War: American Public Opinion and Casualties in Military Conflicts. Princeton: Princeton University Press.

German Marshall Fund of the United States and the Compagnia di San Paolo. (2007) Transatlantic Trends: Key Findings 2007. Washington, DC: German Marshall Fund.

Goldsmith, Benjamin, Yusaku Horiuchi, and Takashi Inoguchi. (2005) Who Supported the War in Afghanistan. The Journal of Conflict Resolution 49: 408-429.

Graaf, Beatrice A. De. (2011) Evaluating Counterterrorism Performance. A Comparative Study. London/ New York: Routledge.

Hazelbag, Lenny J. (2009) Political Decision Making of the Mission in Uruzgan: A reconstruction. In NL-ARMS 2009, Complex operations: Studies on Lebanon (2006) and Afghanistan (2006-present), edited 
by Michiel Weger de, Frans Osinga, and Harry Kirkels. Breda: Netherlands Defence Academy, 251-276.

Hobolt, Sara B., and Robert Klemmensen. (2005) Responsive Government? Public Opinion and Policy Preferences in Britain and Denmark. Political Studies 53: 379-402.

Hobolt, Sara B., and Robert Klemmensen. (2008) Government Responsiveness and Political Competition in Comparative Perspective. Comparative Political Studies 41: 309-337.

Hofland, Hendrik J.A. (2010) Het Nationale Erin Rommelen. Groene Amsterdammer, 136. Available at http://www.groene.nl/2010/6/. (Accessed October 24, 2013.)

Holsti, Ole R. (1992) Public Opinion and Foreign Policy: Challenges to the Almond-Lippmann Consensus. International Studies Quarterly 36: 439-466.

Holsti, Ole R. (2004) Public Opinion and American Foreign Policy. Ann Arbor: University of Michigan Press.

Jacobs, Lawrence R., and Robert Y. Shapiro. (2000) Politicians don't Pander: Political Manipulation and the Loss of Democratic Responsiveness. Chicago: University of Chicago Press.

Jentleson, Bruce W. (1992) The Pretty Prudent Public: Post post-Vietnam American Opinion on the Use of Military Force. International Studies Quarterly 36: 49-73.

KLarevas, Louis. (2002) The 'Essential Domino' of Military Operations: American Public Opinion and the Use of Force. International Studies Perspectives 3: 417-437.

KLeP, Christ. (2011) Uruzgan, Nederlandse militairen op missie, 2005-2010. Amsterdam: Boom.

Klep, Christ, and Richard Gils van. (2005) Van Korea tot Kabul. De Nederlandse militaire deelname aan vredesoperaties sinds 1945. Den Haag: SDU.

Knecht, Thomas, and M. Stephen Weatherford. (2006) Public Opinion and Foreign Policy: The Stages of Presidential Decision Making. International Studies Quarterly 50: 705-727.

Koelé, Theo. (July 5, 2006) We gaan doen wat nodig en mogelijk is. Volkskrant.

Kreps, Sarah. (2010) Elite Consensus as a Determinant of Alliance Cohesion: Why Public Opinion Hardly Matters for NATO-led Operations in Afghanistan. Foreign Policy Analysis 6: 191-215.

Kull, Steven, and I. Mac Destler. (1999) Misreading the Public: The Myth of a New Isolationism. Washington, DC: Brookings.

Ladd, Everett C. (1980) Send in the Marines... Sometimes. Public Opinion 3: 25-26.

Larson, Eric, and Bogdan Savych. (2007) Misfortunes of War: Press and Public Reactions to Civilian Deaths in Wartime. Santa Monica, CA: RAND Corporation.

Lau, Richard, and David Redlawsk. (1997) Voting Correctly. American Political Science Review 91: 585598.

VAN DER LeIJ, Jos. (2009) Maatschappelijk draagvlak internationale inzet krijgsmacht en communicatie: verwerven en behouden. [Public support for the international deployment of armed forces and communication. Achieving and preserving]. Thesis at Higher Defence College. Den Haag: Netherlands Defence Academy.

Louw, Eric. (2010) The Media and Political Process. London: Sage Publications.

Lupia, Arthur, and Matthew D. McCubbins. (1998) The Democratic Dilemma: Can Citizens Learn what They Need to Know? New York: Cambridge University Press.

LutTwak, Edward N. (1996) A Post-Heroic Military Policy: The New Season of Bellicosity. Foreign Affairs 75 (4): 33-44.

Mattern Bially, Janice. (2005) Ordering International Politics: Identity, Crisis and Representational Force. London: Routledge.

Ministry of Defense. (2006) Kamp bezoekt Uruzgan. June 21, 2006. Available at http://www.defensie. nl. (Accessed June 16, 2013.)

Ministry of General Affairs. (2006) Belevingsmonitor winter 2005/2006: Onderzoek naar de beleving van maatschappelijke onderwerpen door de Nederlandse bevolking. Den Haag: Voorlichtingsraad.

Miskimmon, Alistair, Ben O'Loughlin, and Laura Roselle. (2012) Forging the World: Strategic Narratives and International Relations. London: Centre for European Politics/New Political Communications Unit.

Molander, Roger C. (1996) Strategic Information Warfare: The New Face of War. Santa Monica, CA: RAND Corporation.

Morgenthau, Hans. ([1948] 1973) Politics Among Nations: The Struggle for Power and Peace. Boston: Random House.

Mueller, John. (1973) War, Presidents and Public Opinion. New York: Wiley.

Mueller, John. (2005) The Iraq Syndrome. Foreign Affairs 84 (6): 44-54.

Mumby, Dennis K. (1993) Introduction, Narrative and Social Control. In Narrative and Social Control: Critical Perspectives, edited by Dennis K. Mumby. London: Sage.

Neuman, Johanna. (1996) Lights, Camera, War: Is media Technology Driving International Politics? New York: St. Martin's. 
Noll, Jörg, and René Moelker. (2013) Netherlands. In Strategic Cultures in Europe: Security and Defence Policies Across the Continent, edited by Heiko Biehl, Bastian Giegerich, and Alexandra Jonas. Wiesbaden: Springer.

NOVA. (December 22, 2005) Television Interview with Henk Kamp Available at www.novatv.nl. (Accessed June 12, 2013.)

NOVA. (June 9, 2006a) Television Interview with Henk Kamp Available at www.novatv.nl. (Accessed June 12, 2013.)

NOVA. (June 13, 2006b) Television Interview with Henk Kamp Available at www.novatv.nl. (Accessed June 14, 2013.)

Page, Benjamin, and Robert Shapiro. (1983) Effects of Public Opinion on Policy. American Political Science Review 77: 175-190.

Parkinson, John. (2003) Legitimacy Problems in Deliberative Democracy. Political Studies 15: 180-196.

Ringsmose, Jens, and Berit Børgesen. (2011) Shaping Public Attitudes toward the Deployment of Military Power: NATO, Afghanistan and the Use of Strategic Narratives. European Security 20: 505528.

Rosanvallon, Pierre. (2008) Counter-Democracy: Politics in an Age of Distrust. Cambridge: Cambridge University Press.

Roselle, Laura. (2010) Strategic Narratives of War: Fear of Entrapment and Abandonment During Protracted Conflict. Paper presented at Standing Group of International Relations (SGIR) Conference. Available at http://www.stockholm.sgir.eu/. (Accessed September 20, 2013.)

Sapolsky, Harvey, and Jeremy Shapiro. (1996) Casualties, Technology, and America's Future Wars. Parameters 26: 119-127.

Sobel, Richard. (1993) What have We Learned about Public Opinion in U.S. Foreign Policy? In Public Opinion in U.S. Foreign Policy: The Controversy Over Contra Aid, edited by Richard Sobel. Lanham, MD: Rowman \& Littlefield, 269-278.

Stone, Deborah. (2011) Policy Paradox: The Art of Political Decision Making. New York: Norton.

Suhrke, Astri. (2008) A Contradictory Mission? NATO from Stabilization to Combat in Afghanistan. International Peacekeeping 15: 214-236.

The Netherlands. Parliament. Second Chamber records. Various years. Parlementaire Handelingen [abbreviated in the text as: Official Parliamentary Reports], 27925, no. 79, 193, 201, 222, 247, 279, 328, and 330. The Hague: Staatsuitgeverij.

Toespraak van de Commandant der Strijdkrachten, Generaal P.J.M. van Uhm ter gelegenheid van de ISAF-Medaille-uitreiking te Zwolle. (September 26, 2008) Available at www.defensie.nl. (Accessed September 12, 2013.)

VAn der Lijn, JAïr. (2011) 3D “The Next Generation” Lessons Learned From Uruzgan for Future Operations. Den Haag: Netherlands Institute of International Relations "Clingendael."

Van der Meulen, Jan S., and Amber J.V.M. Vos. (2008) De Publieke Opinie Over Uruzgan. Militaire Spectator 177: 393-402.

Van Griensven, Hans. (2007) “'It's all about the Afghan People': Eén jaar 1(NLD/AUS) Task Force Uruzgan." Atlantisch Perspectief 17 (6): 4-10. ['It's all about the Afghan people': One year one (Dutch/Australian) Task Force Uruzgan]

Van Rejjn, Marines Major-General (retired) J.A. (2007) De missie Uruzgan: politieke besluitvorming. Carré 30 (5): 20-24.

Verba, Sidney, Richard A. Brody, Edwin B. Parker, Norman H. Nie, Nelson W. Polsby, Paul Ekman, and Gordon S. Black. (1967) Public Opinion and the War in Vietnam. American Political Science Review 61: 317-333.

Voogd, Remko, and Amber J.V.M. Vos. (2010) Publieke Steun Voor de Missie in Uruzgan, Welke Factoren Bepalen Het Draagvlak? Militaire Spectator 179: 440-453. [Public support for the mission in Uruzgan, Which factors determine the political foundation?]

WeCke, LeOn. (2008) Legitimation of Military Operations. In Beyond the UN Charter: Peace, security and the role of justice, edited by Olivier Ribbelink. The Hague: Hague Academic Press, 145-162.

Wendt, Alexander. (1992) Anarchy is What States Make of it: The Social Construction of Power Politics. International Organization 46: 391-425.

Whezien, Christopher. (1996) Dynamics of Representation: The Case of US Spending on Defence. British Journal of Political Science 26: 81-103.

Woordenspel Afghanistan: Besluit dat geen Besluit heEt. (January 14, 2006) Volkskrant.

Zaller, John. (1994) Elite Leadership of Mass Opinion. In Taken by the Storm: The Media, Public Opinion, and U.S. Foreign Policy in the Gulf War, edited by W. Lance Bennett and David L. Paletz. Chicago: University of Chicago Press. 